\title{
Combining ability and inheritance studies for morphological and yield contributing attributes through line $\times$ tester mating design in wheat (Triticum aestivum $\mathrm{L}$.)
}

\author{
Muhammad Ishaq ${ }^{1 *}$, Gulzar Ahmad ${ }^{1}$, Khilwat Afridi ${ }^{1}$, Murad Ali ${ }^{1}$, \\ Tanzim Ullah Khan ${ }^{1}$, Irfan Ahmad Shah ${ }^{1}$, Bilal Ahmad ${ }^{1}$, Nazir Ahmad ${ }^{2}$, \\ Imtiaz Ahmad ${ }^{2}$, Amir Saleem ${ }^{1}$ and Muhammad Miraj ${ }^{3}$ \\ 1. Cereal Crops Research Institute (CCRI), Pirsabak Nowshera Khyber Pakhtunkhwa-Pakistan \\ 2. Agricultural Research Institute, Tarnab Peshawar Khyber Pakhtunkhwa-Pakistan \\ 3. Department of Plant Breeding and Genetics, The University of Agriculture, Peshawar-Pakistan \\ *Corresponding author's email: ishaqaup@gmail.com \\ Citation \\ Muhammad Ishaq, Gulzar Ahmad, Khilwat Afridi, Murad Ali, Tanzim Ullah Khan, Irfan Ahmad Shah, Bilal \\ Ahmad, Nazir Ahmad, Imtiaz Ahmad, Amir Saleem and Muhammad Miraj. Pure and Applied Biology. Vol. 7, Issue \\ 1, pp160-168. http://dx.doi.org/10.19045/bspab.2018.70019
}

\begin{tabular}{llll}
\hline \hline Received: 07/09/2017 & Revised: 05/01/2018 & Accepted: 05/01/2018 & Online First: 17/01/2018 \\
\hline \hline
\end{tabular}

\section{Abstract}

In wheat improvement programs development of new high yielding varieties requires information about, inheritance mechanism, identification of superior germplasm and combining ability of parents to transmit desirable attributes to offspring. In the current study, three genetically diverse elite advanced lines i.e. PR105, PR-108 and PR-109 and three commercial wheat cultivars Faisalabad -2008, Lasani-2008 and Pirsabak-2013 were sown in crossing block during 2013-14. They were crossed in line $\times$ tester mating design to develop $F_{1}$ hybrids. $F_{1}$ hybrids along with their parents were evaluated in randomized complete block design with three replications at Cereal Crops Research Institute Pirsabak, Nowshera Khyber Pakhtunkhwa-Pakistan during 2014-15 for seven important traits. Analysis of variance revealed highly significant $(\mathrm{P} \leq 0.01)$ differences among the genotypes for the studied traits. Based on desirable General Combining Ability (GCA) effects, among the lines and testers, line (PR-105) and tester (Faisalabad-2008) were found best for earlier heading, maturity and high grain yield. Based on desirable Specific Combining Ability (SCA) effects, crosses, PR-109 $\times$ Lasani-2008 (for days to heading and maturity), PR-108 $\times$ Pirsabak-2013 (for flag leaf area), (PR-108 $\times$ Faisalabad-2008 (for biological yield) and PR-105 $\times$ Lasani2008 (for grain yield) were best specific hybrids involving high $\times$ low and high $\times$ high GCA effects of parents and could be advanced to later segregating generation to extract potential transgressive segregants lines. Contribution of lines $\times$ tester interaction to the total variation was greater than lines and testers individually, indicating greater potential/variation of hybrids appearing for most of the traits. Ratio of GCA variance to SCA variance showed predominance of non additive gene action for all the studied traits. The identified superior crosses could be advanced through mass selection and therefore, single plant selection should be delayed to late segregating generations $\left(\mathrm{F}_{6}\right)$ to derived potential lines for economically important traits.

Keywords: Combining Ability; Gene Action; Line $\times$ Tester; Mating Design; Variance Components; Yield 


\section{Introduction}

Wheat (Triticum aestivum L.) is one of the leading cereal crops grown worldwide in a diversified geographical locations and environments ranging from high to low inputs. It is the most important food grains crop especially in many developing countries of the world and plays a vital role in food security. Globally wheat is the leading source of vegetable protein and has higher protein content then other major cereal like maize and rice. It has been reported that globally wheat provides approximately $55 \%$ carbohydrates and $20 \%$ of the food calories consumed [1]. Global demand for cereal grains consumption is consistently increasing due to ever increasing population of the world. However demand for wheat cannot meet because wheat production in many countries of the world, facing several challenges and are threatened by climatic change. Therefore, introducing new cultivars/ advanced lines with superior features like high yield, disease resistance and its adaptation to arid and semi-arid environments to diversified cultivars basis are prerequisites to feed the ever increasing population [2].

Grain yield is a polygenic trait; hence selection of genotypes based on grain yield alone is not very efficient therefore, to increase breeding efficiency identification of traits by wheat breeder contributing to final yield is of grater important [2, 3]. Modern wheat breeding emphasis on development of new high yielding varieties suited best diversified agro-climatic conditions. This requires information about genetic diversity existed in the available germplasm, inheritance mechanisms operative for the yield and its contributing traits. It can be achieved by breeders through identification/selection of superior germplasm and crossed them with each other using different crossing pattern to generate new variability and wheat plants with elevated levels of genetic diversity and/or recombination.

Selection of desirable/suitable parents and choice of the mating design is the key to success of plant breeding programs. In crop breeding or cultivar development several mating designs like bi-parental mating, ploycross, diallel mating, line $\times$ tester etc are used by plant breeders and geneticists to generate new populations and provide a base for further selection and develop new potential genotypes of desirable attributes [4, 5]. Line $\times$ tester is one of the mating designs proposed by [6] used by breeder to identify potential parents in term of their performance in different cross combinations. It provides information about general combining ability (GCA) of lines/parents and specific combining ability (SCA) of crosses. Furthermore it elucidates the nature of gene action and the inheritance mechanisms for various traits. Line $\times$ tester analysis determine combining ability of parents and exploring gene action for economically important traits has been reported by many researchers [7-9].

Current research was undertaken in wheat through line $\times$ tester analysis with the objectives to (i) Explore spring $\times$ spring, gene pool for economically important traits (ii) Identify potential lines, testers based on general combining ability (GCA) and their $\mathrm{F}_{1}$ hybrids via specific combining ability (SCA) effects to be utilized in future wheat improvement programs (iii) Determine the mode of gene action and inheritance pattern operative for morphological, yield and it associated traits.

\section{Materials and Methods}

\section{Breeding material and experimental site:}

The research was conducted at Cereal Crops

Research Institute (CCRI), Pirsabak Nowshera, Khyber Pakhtunkhwa-Pakistan. The experimental site elevation is 288 meters $(945 \mathrm{Ft})$ and located on the intersection of longitude $740 \mathrm{E}$ and latitude $320 \mathrm{~N}$. Breeding 
material comprised of three diverse advanced lines i.e. PR-105, PR-108 and PR-109 designated as females and three wheat cultivars Faisalabad -2008, Lasani-2008 and Pirsabak-2013 of diverse origin which were used as males. The detail of the lines (females) and testers (males) used in the study are presented in (Table 1). Three lines and three testers were sown in crossing block during 2013-14 and were crossed in line $x$ tester fashion to develop nine $\mathrm{F}_{1}$ hybrids. All the genotypes ( 3 lines, 3 testers and their $9 \mathrm{~F}_{1}$ hybrids) were evaluated in randomized complete block design with three replications during 2014-15. $F_{1}$ hybrids along with their parents were sown in the field in 2 rows of 2 meter long with row spacing of $30 \mathrm{~cm}$ and plant to plant distance $15 \mathrm{~cm}$. Standard cultural practices like irrigation; weeding management and fertilization of were carried out during the cropping seasons.

Table 1. Detail of the lines and testers (cultivars) crossed in line $\times$ tester mating design

\begin{tabular}{|c|c|c|c|}
\hline Parents & Parentage & Selection History & Breeding Institute \\
\hline \multicolumn{4}{|l|}{ Lines } \\
\hline PR-105 & MILAN/S87230//BABAX & $\begin{array}{c}\text { CMSS97M03689T-040Y- } \\
\text { 030M-020Y-030M-015Y-30M- } \\
\text { 3Y-1M-0Y }\end{array}$ & $\begin{array}{l}\text { Cereal Crops Research } \\
\text { Institute(CCRI) Pirsabak } \\
\text { Nowshera, Pakistan } \\
\end{array}$ \\
\hline PR-108 & WHEAR/KRONSTADF2004 & $\begin{array}{c}\text { CGSS04Y00106S-099Y-099M- } \\
\text { 099Y-099M-13WGY-0B }\end{array}$ & -do- \\
\hline PR-109 & $\begin{array}{c}\text { PBW343*2/KUKUNA/5/CNO } \\
\text { 79//PF70354/MUS/3/PASTOR } \\
\text { /4/BA V92 }\end{array}$ & $\begin{array}{c}\text { CGSS03B00180S-099M-099Y- } \\
\text { 099M-17WGY-0B }\end{array}$ & - do- \\
\hline \multicolumn{4}{|l|}{ Testers } \\
\hline Faisalabad -2008 & PBW65/2*PASTOR & $\begin{array}{c}\text { CGSS97Y000367-099T0PB- } \\
\text { 067Y-099M-099Y-099B-16Y- } \\
\text { 0B }\end{array}$ & $\begin{array}{c}\text { Ayub Agriculture } \\
\text { Research Institute } \\
\text { (AARI), Faisalabad } \\
\text { Pakistan }\end{array}$ \\
\hline Lasani-2008 & LUAN/KOH97 & $\begin{array}{l}\text { PBP.29645-14A-18A-8A-4A- } \\
\text { 2A-0A }\end{array}$ & -do- \\
\hline Pirsabak-2013 & $\begin{array}{c}\text { CS/TH.SC//3*PVN/3/MIRLO/ } \\
\text { BUC/4/MILAN/5/TILHI }\end{array}$ & $\begin{array}{l}\text { CMSS97M04005T-040Y- } \\
\text { 020Y-030M-020Y-040M-28Y- } \\
\text { 3M-0Y }\end{array}$ & $\begin{array}{l}\text { Cereal Crops Research } \\
\text { Institute(CCRI) Pirsabak } \\
\text { Nowshera, Pakistan }\end{array}$ \\
\hline
\end{tabular}

Data recording and statistical analysis

Data were recorded on days to heading, heading to maturity, flag leaf area $\left(\mathrm{cm}^{2}\right)$, spike length $(\mathrm{cm})$, spikelets spike $^{-1}$, biological yield $\left(\mathrm{g} \mathrm{plant}^{-1}\right)$ and grain yield ( $\mathrm{g}$ plant $\left.^{-1}\right)$. Recorded data were analyzed according to [10] to determine significant differences among the genotypes and for means comparison least significant difference (LSD) test was used. Traits showing significant genotypic differences were further analyzed for combining ability studies. Line $\times$ tester analysis following [11] was used to estimates of combining ability i.e. general combining ability (GCA) of lines and testers and specific combining ability (SCA) of the hybrids. Proportional (\%) contribution of lines, testers, line $\times$ testers to the total variation was also determined for each trait. Variance due to General combining ability $\left(\sigma^{2} \mathrm{GCA}\right)$, specific combining ability $\left(\sigma^{2} \mathrm{SCA}\right)$, ratio of $\sigma^{2} \mathrm{GCA} / \sigma^{2} \mathrm{SCA}$, for various traits were computed as per [12].

\section{Results and discussion}

Analysis of variation and mean performance of parents (lines, testers) and hybrids

Statistical analysis of data revealed highly significant differences $(\mathrm{P} \leq 0.01)$ among the 
genotypes, parents, lines, crosses and line $\times$ testers for flowering and yield associated traits. However lines effect for days to heading and testers were found nonsignificant for days to maturity, flag leaf area, spike length, biological yield and grain yield (Table 2). Results of the mean performance of lines, testers and their $\mathrm{F}_{1}$ hybrids for the studied traits are provided in (Table 3 ). Based on mean performance for days to heading among the lines, PR-109 and among the testers, Pirsabak-2013 were best as it starts heading and matured earlier. Among the hybrids PR-105 × Faisalabad-2008 (123.0 days) and PR-108 $\times$ Faisalabad-2008 \& PR$108 \times$ Pirsabak-2013 (123.7 days) were found best for days to heading. For days to maturity crosses i.e. PR-105 $\times$ Faisalabad2008 and PR-108 $\times$ Pirsabak-2013 (163.0 days) were best. Among the lines based on mean values PR-105 was best for flag leaf area, spike length, spikelets per spike, biological yield and grain yield. Among the testers, Faisalabad -2008 for flag leaf area, biological yield and grain yield and Pirsabak2013 for spike length and spikelets per spike were best. Among the crosses, PR-109 $\times$ Lasani-2008 (for flag leaf area), PR-108 $\times$ Faisalabad-2008 (spike length and spikelets per spike), PR-105 × Lasani-2008 (for biological yield) and PR-109 $\times$ Faisalabad2008 (for grain yield) were found best (Table 3). Mean values showed that hybrids performance was better than their lines and testers for most of the studied traits. Results regarding studied traits indicated the lines and testers used in the current research were diverse and varied significantly. Significant variation for flowering and yield traits have been reported by [13-16].

Table 2. Analysis of variance (ANOVA) for morphological and yield associated traits using line $\times$ tester mating design in bread wheat

\begin{tabular}{|l|l|l|l|l|l|l|l|l|}
\hline Source of variation & D. F & $\begin{array}{l}\text { Days to } \\
\text { heading }\end{array}$ & $\begin{array}{l}\text { Days to } \\
\text { maturity }\end{array}$ & $\begin{array}{l}\text { Flag leaf } \\
\text { area }\end{array}$ & $\begin{array}{l}\text { Spike } \\
\text { length }\end{array}$ & $\begin{array}{l}\text { Spikelets } \\
\text { per spike }\end{array}$ & $\begin{array}{l}\text { Biological } \\
\text { yield }\end{array}$ & $\begin{array}{l}\text { Grain } \\
\text { yield }\end{array}$ \\
\hline Replications & 2 & 14.16 & 8.96 & 97.75 & 6.94 & 11.25 & 51.46 & 73.63 \\
\hline Genotypes & 14 & $14.57^{* *}$ & $8.31^{* *}$ & $63.35^{* *}$ & $2.35^{* *}$ & $5.84^{* *}$ & $518.83^{* *}$ & $70.53^{* *}$ \\
\hline Parents & 5 & $12.89^{* *}$ & $18.32^{* *}$ & $48.40^{*}$ & $2.11^{* *}$ & $3.28^{*}$ & $443.02^{*}$ & $66.70^{* *}$ \\
\hline Parents vs Crosses & 1 & $56.95^{* *}$ & $6.85^{* *}$ & $250.12^{* *}$ & $1.24^{\mathrm{NS}}$ & $1.15^{\mathrm{NS}}$ & $623.01^{* *}$ & $88.95^{* *}$ \\
\hline Crosses & 8 & $10.31^{* *}$ & $2.23^{* *}$ & $49.34^{* *}$ & $2.63^{* *}$ & $8.02^{* *}$ & $553.19^{* *}$ & $70.62^{* *}$ \\
\hline Lines & 2 & $1.81^{\mathrm{NS}}$ & $3.37^{* *}$ & $46.28^{*}$ & $1.61^{*}$ & $4.22^{*}$ & $1280.73^{* *}$ & $144.24^{* *}$ \\
\hline Testers & 2 & $23.59^{* *}$ & $1.59^{\mathrm{NS}}$ & $27.18^{\mathrm{NS}}$ & $0.82^{\mathrm{NS}}$ & $6.92^{* *}$ & $44.74^{\mathrm{NS}}$ & $8.29^{\mathrm{NS}}$ \\
\hline Lines $\times$ Testers & 4 & $7.93^{* *}$ & $1.98^{*}$ & $61.95^{* *}$ & $4.05^{* *}$ & $10.46^{* *}$ & $443.64^{* *}$ & $64.96^{* *}$ \\
\hline Error & 28 & 2.49 & 1.15 & 24.71 & 0.73 & 1.64 & $199.92^{* *}$ & 26.63 \\
\hline
\end{tabular}

$* \& * *=$ Significant at $5 \%$ and $1 \%$ level of probability, respectively NS $=$ Non significant

Table 3. Mean performance of lines, testers and their $F_{1}$ hybrids for morphological and yield traits in bread wheat

\begin{tabular}{|l|l|l|l|l|l|l|l|}
\hline Genotypes & $\begin{array}{l}\text { Days to } \\
\text { heading }\end{array}$ & $\begin{array}{l}\text { Days to } \\
\text { maturity }\end{array}$ & $\begin{array}{l}\text { Flag leaf } \\
\left.\text { area } \mathbf{( c m}^{\mathbf{2}}\right)\end{array}$ & $\begin{array}{l}\text { Spike } \\
\text { length }(\mathbf{c m})\end{array}$ & $\begin{array}{l}\text { Spikelets } \\
\text { per spike }\end{array}$ & $\begin{array}{l}\text { Biological yield } \\
\left.\text { (g plant }^{-1}\right)\end{array}$ & $\begin{array}{l}\text { Grain yield } \\
\left.\mathbf{g ~ p l a n t ~}^{-1}\right)\end{array}$ \\
\hline Lines & & & & & & & \\
\hline PR-105 & 123.3 & 165.0 & 49.96 & 14.42 & 22.9 & 102.15 & 39.37 \\
\hline PR-108 & 124.0 & 164.7 & 38.39 & 13.42 & 21.8 & 76.42 & 27.65 \\
\hline PR-109 & 121.3 & 164.0 & 43.28 & 12.33 & 21.3 & 93.72 & 32.35 \\
\hline Testers & & & & & & & \\
\hline Faisalabad -2008 & 123.7 & 163.7 & 44.09 & 13.09 & 20.1 & 110.50 & 38.37 \\
\hline Lasani-2008 & 125.0 & 164.0 & 40.83 & 14.22 & 22.7 & 84.69 & 29.47 \\
\hline Pirsabak-2013 & 119.3 & 158.3 & 40.75 & 12.64 & 21.0 & 95.92 & 34.61 \\
\hline F hybrids & & & & & & & \\
\hline
\end{tabular}




\begin{tabular}{|c|c|c|c|c|c|c|c|}
\hline $\begin{array}{l}\text { PR-105 } \\
\text { Faisalabad-2008 }\end{array}$ & 123.0 & 163.0 & 45.65 & 12.80 & 21.9 & 88.83 & 34.95 \\
\hline $\begin{array}{l}\text { PR-105 × Lasani- } \\
2008\end{array}$ & 126.0 & 163.7 & 51.81 & 13.70 & 18.2 & 120.11 & 41.92 \\
\hline $\begin{array}{ll}\text { PR-105 } & \times \\
\text { Pirsabak-2013 } & \end{array}$ & 125.0 & 163.7 & 46.28 & 13.43 & 23.4 & 103.22 & 37.91 \\
\hline $\begin{array}{l}\text { PR-108 } \\
\text { Faisalabad-2008 }\end{array}$ & 123.7 & 164.7 & 49.11 & 16.00 & 23.5 & 96.56 & 32.48 \\
\hline $\begin{array}{l}\text { PR-108 × Lasani- } \\
2008\end{array}$ & 129.3 & 164.7 & 41.81 & 13.50 & 21.8 & 80.78 & 31.33 \\
\hline $\begin{array}{ll}\text { PR-108 } & \times \\
\text { Pirsabak-2013 } & \\
\end{array}$ & 123.7 & 163.0 & 45.05 & 12.94 & 21.2 & 88.15 & 31.96 \\
\hline $\begin{array}{l}\text { PR-109 } \\
\text { Faisalabad-2008 }\end{array}$ & 124.7 & 163.7 & 45.70 & 13.29 & 21.6 & 112.18 & 44.58 \\
\hline $\begin{array}{l}\text { PR-109 × Lasani- } \\
2008\end{array}$ & 125.3 & 165.3 & 55.47 & 13.62 & 22.8 & 110.03 & 33.12 \\
\hline $\begin{array}{ll}\text { PR-109 } & \times \\
\text { Pirsabak-2013 } & \end{array}$ & 125.0 & 165.0 & 48.37 & 13.96 & 23.1 & 113.60 & 40.30 \\
\hline Lines mean & 122.9 & 164.6 & 43.88 & 13.39 & 22.0 & 90.76 & 33.12 \\
\hline Testers mean & 122.7 & 162.0 & 41.89 & 13.32 & 21.3 & 97.04 & 34.15 \\
\hline $\mathrm{F}_{1}$ mean & 125.1 & 164.1 & 47.69 & 13.69 & 22.0 & 101.50 & 36.51 \\
\hline $\operatorname{LSD}_{(0.05)}$ & 2.6 & 1.8 & 8.31 & 1.43 & 2.1 & 23.65 & 8.63 \\
\hline $\operatorname{LSD}_{(0.01)}$ & 3.6 & 2.4 & 11.22 & 1.93 & 2.9 & 31.90 & 11.64 \\
\hline
\end{tabular}

LSD = Least significant difference

\section{General combining ability effects}

General combining ability is of significant importance and widely used by plant breeders to identify potential lines and testers to be used in future crossing programs and selecting superior lines in segregating population from resultant hybrids of these lines [17-18]. General combining ability effects of lines and testers for the studied traits are presented in (Table 4). Wheat breeders are interested in development of new genotypes starts heading and mature earlier. Therefore for days to heading and maturity negative combining ability effects are desirable. Among the lines, best general combiner were PR-105 for days to heading ($0.41)$ and maturity (-0.63), PR-109 for flag leaf area (2.15). Spiketets per spike (0.54), biological yield (10.44) and grain yield (2.83). However among the testers, Faisalabad-2008 was best general combiner for earlier heading (-1.30) and maturity ($0.30)$, spike length (0.34) and grain yield (0.83). Similar findings were also reported by [19] for days to heading, plant height, spike length and spikelets per spike. [20] also proposed that lines with positive GCA effects for important parameters should be used in future breeding programs to improve wheat yield.

Table 4. Estimates of general combining ability (GCA) of 6 Parents ( 3 lines and 3 testers) for the studied traits in bread wheat

\begin{tabular}{|l|l|l|l|l|l|l|l|}
\hline Parents & $\begin{array}{l}\text { Days to } \\
\text { heading }\end{array}$ & $\begin{array}{l}\text { Days to } \\
\text { maturity }\end{array}$ & $\begin{array}{l}\text { Flag leaf } \\
\text { area }\end{array}$ & $\begin{array}{l}\text { Spike } \\
\text { length }\end{array}$ & $\begin{array}{l}\text { Spikelets per } \\
\text { spike }\end{array}$ & $\begin{array}{l}\text { Biological } \\
\text { yield }\end{array}$ & $\begin{array}{l}\text { Grain } \\
\text { yield }\end{array}$ \\
\hline Lines & & & & & & & \\
\hline PR-105 & -0.41 & -0.63 & 0.22 & -0.38 & -0.77 & 2.56 & 1.75 \\
\hline PR-108 & 0.48 & 0.04 & -2.37 & 0.45 & 0.23 & -13.00 & -4.58 \\
\hline PR-109 & -0.07 & 0.59 & 2.15 & -0.07 & 0.54 & 10.44 & 2.83 \\
\hline SE (lines) & 0.53 & 0.36 & 1.66 & 0.28 & 0.43 & 4.71 & 1.72 \\
\hline
\end{tabular}


Ishaq et al.

\begin{tabular}{|l|l|l|l|l|l|l|l|}
\hline Testers & & & & & & & \\
\hline Faisalabad -2008 & -1.30 & -0.30 & -0.87 & 0.34 & 0.36 & -2.31 & 0.83 \\
\hline Lasani-2008 & 1.81 & 0.48 & 2.00 & -0.09 & -1.00 & 2.14 & -1.05 \\
\hline Pirsabak-2013 & -0.52 & -0.19 & -1.13 & -0.25 & 0.64 & 0.16 & 0.22 \\
\hline SE (Testers) & 0.53 & 0.36 & 1.66 & 0.28 & 0.43 & 4.71 & 1.72 \\
\hline
\end{tabular}

$\mathrm{SE}=$ Standard error

\section{Specific combining ability effects}

Results of specific combining ability effects for the studied traits are presented in Table 5. Development of new wheat genotypes with earlier heading and maturity are the keys to cope with different abiotic stress during crop life cycle. Therefore for these traits hybrids with negative SCA effects are preferred. For days to heading, negative SCA were shown by PR-109 $\times$ Lasani-2008 (-1.48), followed by PR-108 $\times$ Pirsabak-2013 (-1.37) and PR$108 \times$ Faisalabad-2008 (-0.59). Regarding days to maturity, PR-108 × Pirsabak-2013 (0.93), PR-109 $\times$ Faisalabad-2008 (-0.70) and PR-105 × Lasani-2008 (-0.26) were best specific hybrids. More flag leaf area is desirable and cross combinations i.e. PR-108 $\times$ Faisalabad-2008(4.66), PR-109 × Lasani2008 (3.62) and PR-105 $\times$ Lasani-2008 (1.89) were found best. These results confirm the findings of $[21,22]$ who found positive SCA effect for flag leaf area. Long spike with more spikelets per spike are desirable and are important yield contributing parameters. Based on positive SCA values best cross combinations for spike length were PR-108 $\times$ Faisalabad-2008 (1.52), PR-109 × Pirsabak2013 (0.58) and PR-105 × Pirsabak-2013 (1.62) and PR-109 × Lasani-2008 (1.33) for more spiketets per spike. $\mathrm{F}_{1}$ hybrids: PR-105 $\times$ Lasani-2008 (13.91), PR-108 $\times$ Faisalabad2008 (10.37) and PR-109 $\times$ Faisalabad-2008 (2.55) were promising one for biological yield. Pertaining to grain yield per plant best specific hybrids were PR-105 × Lasani-2008 (4.71), PR-109 × Faisalabad-2008 (4.41), PR-109 × Pirsabak-2013 (0.75). Based on SCA effects the superior performance of high $\times$ low, medium $\times$ low and high $\times$ high combinations could be due to the presence of genetic diversity among the lines and tester used in the study. The similar results were also reported earlier by $[23,24]$ for yield and yield associated traits.

Table 5. Estimates of specific combining ability (SCA) effects of $9 \mathrm{~F}_{1}$ hybrids derived from lines $\times$ testers mating design for studied traits in bread wheat

\begin{tabular}{|l|l|l|l|l|l|l|l|}
\hline Crosses & $\begin{array}{l}\text { Days to } \\
\text { heading }\end{array}$ & $\begin{array}{l}\text { Days to } \\
\text { maturity }\end{array}$ & $\begin{array}{l}\text { Flag leaf } \\
\text { area }\end{array}$ & $\begin{array}{l}\text { Spike } \\
\text { length }\end{array}$ & $\begin{array}{l}\text { Spikelets } \\
\text { per spike }\end{array}$ & $\begin{array}{l}\text { Biological } \\
\text { yield }\end{array}$ & $\begin{array}{l}\text { Grain } \\
\text { yield }\end{array}$ \\
\hline PR-105 $\times$ Faisalabad-2008 & -0.37 & -0.15 & -1.39 & -0.85 & 0.34 & -12.91 & -4.14 \\
\hline PR-105 $\times$ Lasani-2008 & -0.48 & -0.26 & 1.89 & 0.48 & -1.96 & 13.91 & 4.71 \\
\hline PR-105 $\times$ Pirsabak-2013 & 0.85 & 0.41 & -0.51 & 0.37 & 1.62 & -1.00 & -0.57 \\
\hline PR-108 $\times$ Faisalabad-2008 & -0.59 & 0.85 & 4.66 & 1.52 & 0.96 & 10.37 & -0.28 \\
\hline PR-108 $\times$ Lasani-2008 & 1.96 & 0.07 & -5.51 & -0.56 & 0.64 & -9.86 & 0.45 \\
\hline PR-108 $\times$ Pirsabak-2013 & -1.37 & -0.93 & 0.85 & -0.95 & -1.60 & -0.50 & -0.18 \\
\hline PR-109 $\times$ Faisalabad-2008 & 0.96 & -0.70 & -3.28 & -0.67 & -1.30 & 2.55 & 4.41 \\
\hline PR-109 $\times$ Lasani-2008 & -1.48 & 0.19 & 3.62 & 0.09 & 1.33 & -4.05 & -5.16 \\
\hline PR-109 $\times$ Pirsabak-2013 & 0.52 & 0.52 & -0.34 & 0.58 & -0.02 & 1.50 & 0.75 \\
\hline SE (SCA) & 0.91 & 0.62 & 2.87 & 0.49 & 0.74 & 8.16 & 2.98 \\
\hline
\end{tabular}

$\mathrm{SE}=$ Standard error 
Proportional contribution of lines, testers and line $x$ tester interaction to the total variance and gene action for the studied traits

For each trait proportional contribution of lines, testers and line $\times$ tester interaction to the total variation are presented in (Figure 1). For days to heading and spikelets per spike of the total variance, the contribution of lines was smaller than the testers and line $\times$ tester interaction effect. Testers contributions for flag leaf area, spike length, biological yield and grain yield was lesser as testers and line $x$ testers interaction effect. Line $x$ testers interaction effect to the total variation for days to maturity, flag leaf area, spike length and spikelets per spike was much more then lines and testers individually. It clearly indicated that line $\times$ tester interaction provide greater variability for appearing of the studied traits. Our results are supported by [35] who reported that line $\times$ tester interaction contributed much for for spike length, spikelets per spike, biological yield and yield per plant. It is also worth mentioning that the $F_{1}$ hybrids had a higher values for days to heading, days to maturity, flag leaf area, spike length, biological yield and grain yield as compared to parents (lines and testers).Variance due to general combining ability $\left(\sigma^{2} \mathrm{GCA}\right)$ value was smaller than specific combining ability $\left(\sigma^{2} S C A\right)$ for all the studied traits indicating predominance of non additive gene action. This was further supported by low ratio of $\sigma^{2} \mathrm{GCA} / \sigma^{2} \mathrm{SCA}$ being less than unity for all the traits studied (Table 6). Our results are supported by [1927] who reported non additive gene action for yield and yield associated traits bread wheat

Table 6. Estimates of variances of general combining ability ( $\sigma^{2}$ gca), specific combining ability ( $\sigma^{2}$ sca) ratio of $\sigma^{2}$ gca/ $\sigma^{2}$ sca, for the studied traits in bread wheat

\begin{tabular}{|l|l|l|l|l|l|l|l|}
\hline Genetic component & $\begin{array}{l}\text { Days to } \\
\text { heading }\end{array}$ & $\begin{array}{l}\text { Day to } \\
\text { maturity }\end{array}$ & $\begin{array}{l}\text { Flag leaf } \\
\text { area }\end{array}$ & $\begin{array}{l}\text { Spike } \\
\text { length }\end{array}$ & $\begin{array}{l}\text { Spikelets } \\
\text { per spike }\end{array}$ & $\begin{array}{l}\text { Biological } \\
\text { yield }\end{array}$ & $\begin{array}{l}\text { Grain } \\
\text { yield }\end{array}$ \\
\hline $\boldsymbol{\sigma}^{2}$ gca & 0.486 & 0.083 & 0.320 & -0.045 & 0.019 & 24.495 & 2.432 \\
\hline $\boldsymbol{\sigma}^{2}$ sca & 1.812 & 0.278 & 12.411 & 1.107 & 2.943 & 81.240 & 12.778 \\
\hline $\boldsymbol{\sigma}^{\mathbf{2}} \mathbf{g c a} / \boldsymbol{\sigma}^{\mathbf{2}}$ sca & 0.268 & 0.297 & 0.026 & -0.041 & 0.006 & 0.302 & 0.190 \\
\hline
\end{tabular}

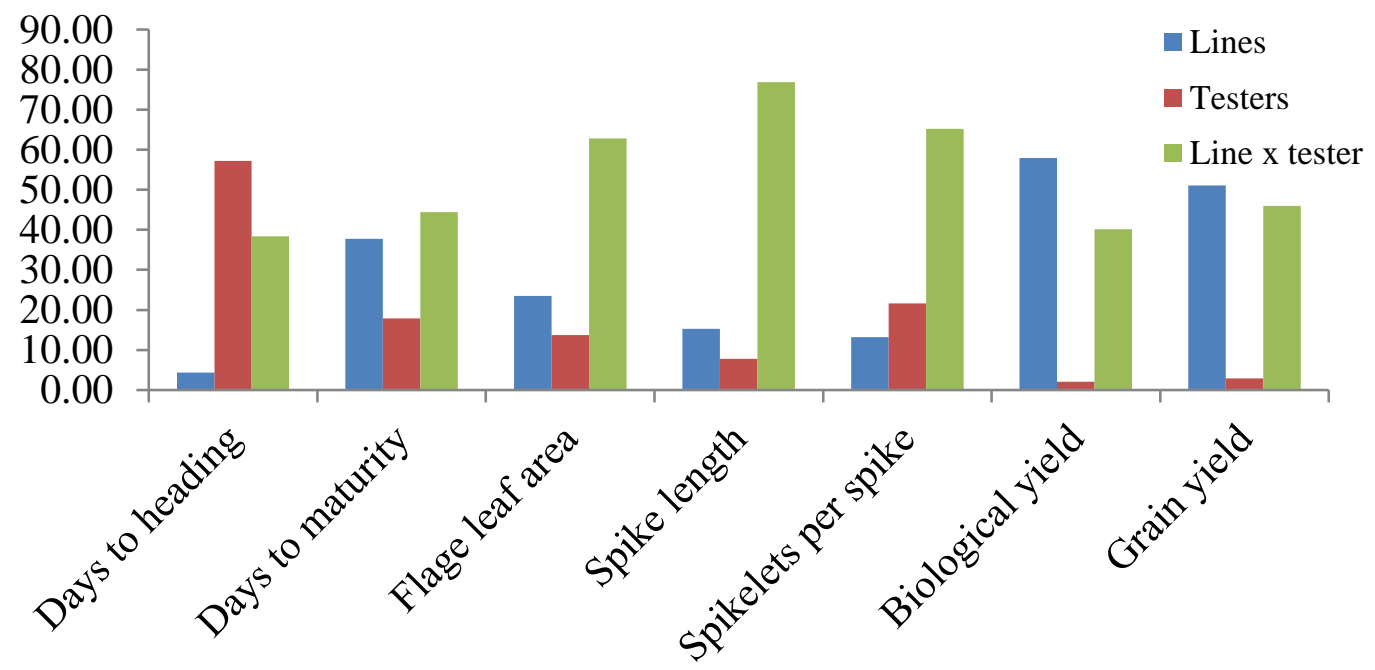

Figure 1. Proportional contribution $(\%)$ of lines, testers and line $\times$ testers' interaction effects to the total variation for the studied traits 


\section{Conclusions}

Analyzed data revealed highly significant differences among the genotypes for all the characters studied. Analysis of line $x$ testers revealed that lines, testers and line $\times$ tester effects were found highly significant for most of the traits. Based on general combining ability among the parents PR-105 and Faisalabad-2008 were found best for earlier heading, maturity and high grain yield per plant. Crosses for days to heading, PR-109 $\times$ Lasani-2008, maturity (PR-108 $\times$ Pirsabak2013) flag leaf area (PR-108 $\times$ Faisalabad2008 (4.66) for biological yield and grain yield (PR-105 × Lasani-2008) was best specific hybrid involving high $\times$ low and high $\times$ high GCA effects of parents. Contribution of lines $x$ tester interaction to the total variation was greater than lines and tester individually, indicating greater potential/variation of hybrids appearing for most of the traits. Non additive gene action for all the studied traits was observed as ratio of GCA variance to SCA variance was less then unity. Due to greater contribution of line $\times$ tester interaction effect, predominance of non-additive gene action, these selected best crosses could be advanced through mass selection and selection should be carried out at later segregating generations $\left(\mathrm{F}_{6}\right.$ and onward) to derive /extracts potential lines for important traits.

\section{Authors' contributions}

Conceived and designed the experiments: $\mathrm{M}$ Ishaq, Performed the experiments: G Ahmad, K Afridi \& M Ali, Analyzed the data: M Ishaq, TU Khan \& B Ahmad, Contributed materials/ analysis/ tools: N Ahmad, I Ahmad, IA Shah, A Saleem \& M Miraj, Wrote the paper: M Ishaq \& K Afridi.

\section{Acknowledgements}

The authors are thankful to Wheat Productivity Enhancement Program (WPEP) Pakistan, a CIMMYT funded project for financial support.

\section{References}

1. Adina B \& Dan G (1995). Wheat Evolution. Israel J of Plant Sci 43(2): 8598.

2. Jatav M, Jatav SK \& Kandalkar VS (2014). Combining ability and heterosis analysis of morpho- physiological characters in wheat. Annals Plant and Soil Res 16(2): 79-83.

3. Saeed M, Khalil IH, Nayab D, Anjum SA \& Tanveer M (2016). Combining ability and heritability for yield traits in wheat (Triticum aestivum L.). Pak J Agric Sci 53(3): 577-583.

4. Kant L, Mani VP \& Gupta HS (2001). Winter $\times$ spring wheat hybridization a promising avenue for yield enhancement. Plant Breed 120:255-259.

5. Akbar M, Anwar J, Hussain M, Qureshi MH \& Khan S (2009). Line $\times$ tester analysis in bread wheat (Triticum aestivum L.). J Agric Res 47(1): 411-420.

6. Kempthrone O (1957). An Introduction to Genetic Statistics. John Wiley and Sons, Inc., New York.

7. Saeed A, Chowdhry MA, Saedd N, Khalıq I, \& Johar MZ (2001). Line $\times$ tester analysis for some morpho-physiological traits in bread wheat. Int J Agric \& Biol 3(4):444447.

8. Krystkowiak K, Adamski T, Surma M \& Kaczmarek Z (2008). Relationship between phenotypic and genetic diversity of parental genotypes and the specific combining ability and heterosis effects in wheat (Triticum aestivum L.). Euphytica 165: 419-434.

9. Jain SK \& Sastry EVD (2012). Heterosis and combining ability for grain yield and its contributing traits in bread wheat (Triticum aestivum L.). J Agric and Alli Sci 1:17-22.

10. Steel RG \& Torrie JH (1980). Principles and procedures of genetics. McGraw Hill Co. Inc. New York

11. Kemthrone O (1957). An introduction to genetical statistics. John Wiley and sons, Inc, Newyork. 
12. Singh RK \& Chaudhary BD (1985). Biometrical methods in quantitative genetic analysis. Kalyani Pub Ludhiana New Delhi.

13. Abro SA, Baloch AW, Baloch M, Baloch GA, Baloch TA, Soomro AA, Jogi Q \& Ali M (2016). Line $\times$ tester analysis for estimating combining ability in $\mathrm{F}_{1}$ hybrids of bread wheat. Pure and Appli Biol 5 (3): 647-652.

14. Ijaz B, Arshad M, Shabbir RH, \& Demir M (2015). Estimation of combining ability for selection of Triticum aestivum L. genotypes with some yield related traits. Commun Plant Sci 5 (3-4) 51-57.

15. Saeed M, \& Khalil IH (2017). Combining ability and narrow-sense heritability in wheat (Triticum aestivum L.) under rainfed environment. Sarhad J Agric 33(1): 22-29.

16. Bibi R, S. Hussain B, Khan AS and Raza I (2013). Assessment of combining ability in bread wheat by using line $\times$ tester analysis under moisture stress conditions. Pak Agric Sci 50(1): 1-5.

17. Majeed S, Sajjad M, \& Khan SH (2011). Exploitation of non-additive gene actions of yield traits for hybrid breeding in spring wheat. J Agric Soc Sci 7: 131-135.

18. Aslam R, Munawar $M$ and Salam A (2014). Genetic architecture of yield components accessed through line $\times$ tester analysis in wheat (Triticum aestivum L.) Universal J Plant Sci 2(5): 93-96.

19. Jatav SK, Baraiya BR \& Kandalkar VS (2017). Combining ability for grain yield and its components different environments in wheat. Int $J$ Current Micro Appli Sci 6(8): 2827-2834.

20. Muneer MA, Nisa ZU, Munir MZ, Imran M, Intikhab A, Adil S, Ain NU \&
Saifullah (2016). Line $\times$ tester analysis for yield contributing morphological traits in Triticum aestivum under drought conditions .Int J Agron and Agric Res 9 (2):57-64.

21. Patial M, Pal D \& Kumar J (2016). Combining ability and gene action studies for grain yield and its component traits in barley (Hordeum vulgare L.) SABRAO J Breed. and Genetics 48 (1) :90-96.

22. Kandil AA, Sharief, A.E. Hasnaa, \& Gomaa, SM (2016). Estimates of gene action for yield and its components in bread wheat (Triticum aestivum L.). Int J Agric Res 8:34-40.

23. Fellahi, ZEA, Hannachi A, Bouzerzour H. $\&$ Boutekrabt A (2013). Line $\times$ tester mating design analysis for grain yield and yield related traits in bread wheat (Triticum aestivum L.). Int J Agron: 1- 9.

24. Joshi SK, Sharma SN, Singhania DL \& Sain RS (2003). Genetic analysis of yield and its component traits in spring wheat (Triticum aestivum L.). Acta Agron. Hungarica 51: 139-147.

25. Muhammad O (2009). Combining ability in wheat for seedling traits by line $\times$ tester analysis under saline conditions. Ital $\mathrm{J}$ Agron 4(2): 13-18.

26. Esmail RM (2007). Detection of genetic components through triple test cross and line $\times$ tester analysis in bread wheat. World J Agric Sci 3: 184-190.

27. Singh A, Kumar A, Swati EA \& Jaiswal JP (2012). Combining ability and gene action studies for seed yield, its components and quality traits in bread wheat (Triticum aestivum L. em Thell.) Electronic J Plant Breed 3(4): 964-972. 